\title{
The Role of Teachers In Reducing Hyperactive Behavior of Children with Special Needs Is Reviewed from The Characteristics of Speed And Balance
}

\author{
Gatot Jariono $^{1}$, Nurhidayat ${ }^{2}$, Eko Sudarmanto ${ }^{3}$, Ardhian Tomy Kurniawan ${ }^{4}$, Chandra \\ Triadi $^{5}$, Maimunah NA ${ }^{6}$ \\ \{gatot.jariono@ums.ac.id ${ }^{1}$ \}
}

Sports Education, Teacher Training and Education Faculty, Universitas Muhammadiyah Surakarta, Indonesia ${ }^{1}$

\begin{abstract}
This study to analyze the role of teachers in reducing the hyperactive behavior of children with special needs reviewed the characteristics of speed and balance. The case study using qualitative and quantitative approaches was used. The samples used in this study were children with special needs in Karanganyar Special School and Sukoharjo Special School as many as 40 respondents with the provisions of 20 male and 20 female. Data analysis techniques use descriptive statistical analysis and inferential analysis. Overall data analysis using the help of Statistical Package for the Social Sciences (SPSS) version 23. The results of this study showed there is a role of teachers in reducing hyperactive behavior of children with special needs reviewed from the characteristics of speed and balance. However, further research is needed involving other modified physical activity variables in reducing hyperactive behavior in children with special needs.
\end{abstract}

Keywords: hyperactivity behavior, speed, balance, children with special needs.

\section{Introduction}

Characteristics of children with special needs consist of the blind, deaf, speech deaf, deaf, deaf, autistic, hyperactive or Attention Deficit Hyperactivity Disorder (ADHD), and double deafness. But in this study only limit children's hyperactivity or Attention Deficit Hyperactivity Disorder (ADHD). Children with special needs, especially those who have hyperactive behavior if do not allow to do the physical activity then the child will not be able to have a qualified physique, and vice versa if the child is allowed to perform physical activity following the needs of motion and gender characteristics through exercises supervised by teachers/trainers who understand about the child's development, then the child will have a qualified quality.

Research on the hyperactive behavior of children with special needs was conducted by many previous researchers, among others in his research to accompany and educate children must understand the characteristics and needs of children with special needs [1]. Castellanos \& Proal stated in accompanying the child ADHD should pay attention to the characteristics of the child's development [2]. Distraction hyperactivity in children the need for attention and mentoring both teachers and parents [3], ADHD children in particular who have emotional disorders [4], hood ADHD, [5] researching about prevalence in children ADHD examined attention disorders in children who have hyperactive behavior [6], [7] in his research suggesting that hyperactive behavior can be identified early as the behavior of children who have a high 
risk both disturbing in the family environment and social environment [8] in his research describing how to care for children with special needs [9] in his research describing the discrimination of children with special needs, and [10] in his research describing how the model of social relations of children with disabilities through the approach of special needs education. However, in the previous study, no one has studied the role of teachers in reducing hyperactive behavior of children with special needs reviewed from gender characteristics and motor skills. Thus the researchers provided one solution in the form of an alternative to reduce the hyperactive behavior of children with special needs reviewed from gender characteristics and motor exercises.

Following the characteristics of children who have hyperactive behavior if given the opportunity to perform motion activities through learning Physical education and sports, automatically the child will be happier in doing motion activities to maintain the quality of physical condition. Doing physical activity is one of the important components to keep the physical condition in shape. To maintain good physical quality, the need to practice structured and systematic physical conditions through the assistance of teachers at least have experience handling hyperactive behavior of children with special needs.

Based on the phenomenon in the form of facts, researchers provide solutions in the form of alternatives, one of which is through scientific studies on the role of teachers in reducing hyperactive behavior of children with special needs reviewed from the characteristics of speed, and balance. Thus, the main purpose of this study is to analyze the role of teachers in reducing the hyperactive behavior of children with special needs reviewed from the characteristics of speed and balance.

\section{Methods}

The survey method used in this study while the design of this study uses comparative. The research was conducted in January-March 2021 at Karanganyar Special School and Sukoharjo Special School, Central Java Province, Indonesia. Target this research is all Special School students in Central Java while the research subjects are students of Karanganyar Special School and Sukoharjo Special School numbered 40 people, with the provision of 20 sons and 20 daughters. Furthermore, the design in this study can be seen in table 1

Table 1. Research design

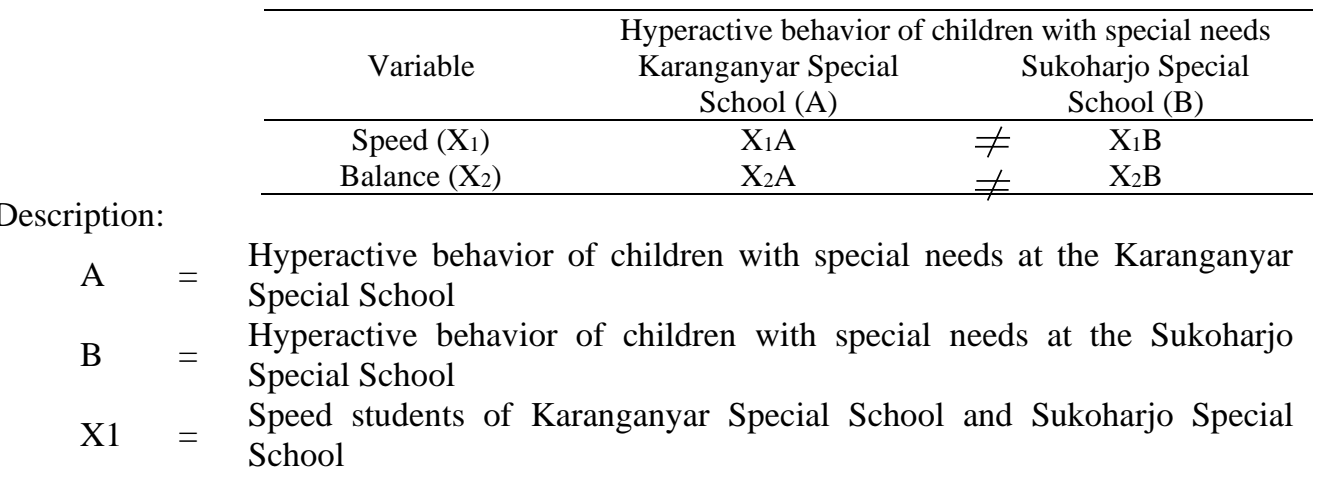




\section{$\mathrm{X} 2=$ Balance students of Karanganyar Special School and Sukoharjo Special School}

In this study there are several steps taken, namely " (1) establishing the group of research subjects; (2) carry out modified speed, and balance tests; (3) carry out a speed test using a 30 meter running test and a standing balance test with one modified leg; (4) looking for the average score of the tests performed and compared between the two; (5) looking for differences between the two averages through speed, and balance tests accompanied by hyperactive behavior in children with special needs following the characteristics of children with special needs use (ttest)"to know whether or not the difference in speed tests and balance modified to reduce hyperactive behavior of children with special needs between Karanganyar Special School and Sukoharjo Special School". The population and samples of this study are Karanganyar Special School and Sukoharjo Special School Central Java Province, using a sample of 20 males and a sample of 20 females aged 10-12 years.

The sample criteria in this study are children in outstanding schools, (ii) This study was approved by respondents through parental consent informed through a statement of approval to be sampled, and (iii) this study put forward ethical, value, and moral principles in the survey research through the modified treatment of speed, and balance tests. Before this study was conducted, researchers held a meeting with the school and the student's families to explore information related to this study about the role of teachers in reducing hyperactive behavior of children with special needs reviewed from the characteristics of speed, and balance. Furthermore, data collected through motor ability tests are analyzed descriptively and inferentially. Descriptive analysis is intended to get an overview of data that includes average values, value ranges, maximum values, and minimum values while inferential analysis is used to test research hypotheses using t-tests at a significant level of $95 \%$ or $\alpha=0.05$. Overall statistical data analysis is used in general using computer systems in SPSS version 23 programs.

\section{Results and discussion}

Based on the results of the descriptive analysis found several things, namely identification about speed, and balance accompanied by hyperactive behavior in children with special needs can be described as follows;

\subsection{Descriptive analysis of data}

Descriptive analysis of data aims to draw in general relation to the distribution of speed and power hyperactive behavior of children with special needs. A recap of the results of the descriptive analysis of the data can be seen in table 2 .

Table 2. Descriptive analysis results of speed, and balance of male

\begin{tabular}{lcc}
\hline \multirow{2}{*}{ Mean } & \multicolumn{2}{c}{ Hyperactive behavior of children with special } \\
& \multicolumn{2}{c}{ needs } \\
\cline { 2 - 3 } & $\begin{array}{ccc}\text { Karanganyar Special } \\
\text { School }\end{array}$ & $\begin{array}{c}\text { Sukoharjo Special } \\
\text { School }\end{array}$ \\
\hline Speed & 4.99 & 5.34 \\
balance & 24.04 & 18.97 \\
\hline
\end{tabular}


Based on the results of the descriptive analysis in table 2 can be concluded that there are differences in speed, and balance of children with special needs have reviewed the characteristics of children. This is evidenced from 20 samples obtained the difference in an average value for speed $4.99-5.34$ difference of 0.35 and balance of $24.04-18.97$ difference of 5.07. Thus, it can be concluded that Karanganyar Special School speed quality and balance are better when compared to Sukoharjo Special School, this is due to one of the characteristics of different regions. Therefore, the role of teachers in reducing the hyperactive behavior of children with special needs varies. Furthermore, after obtaining a descriptive analysis of frequency to strengthen the findings in the field can be seen histogram average value speed, and balance of students on in figure 1

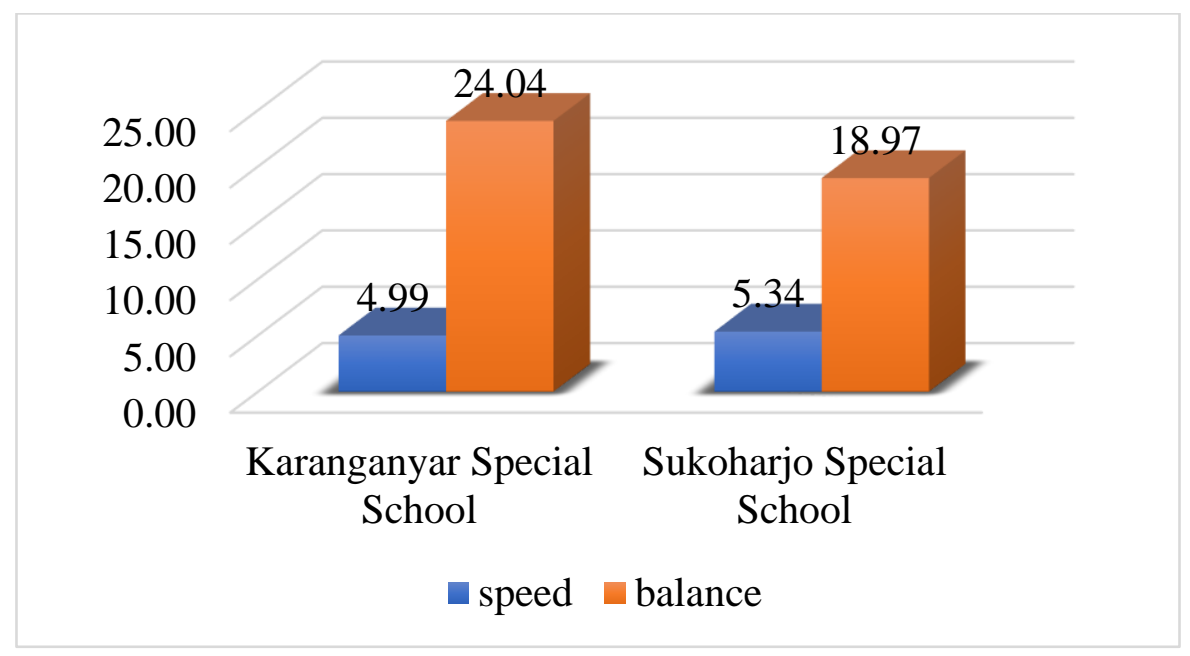

Fig. 1 speed, and balance of male students

Table 3. Descriptive analysis results of speed, and balance of female

\begin{tabular}{lcc}
\hline \multirow{2}{*}{ Mean } & \multicolumn{2}{c}{ Hyperactive behavior of children with special } \\
& \multicolumn{2}{c}{ needs } \\
\cline { 2 - 3 } & $\begin{array}{c}\text { Karanganyar Special } \\
\text { School }\end{array}$ & $\begin{array}{c}\text { Sukoharjo Special } \\
\text { School }\end{array}$ \\
\hline Speed & 6.16 & 7.31 \\
balance & 19.75 & 14.66 \\
\hline
\end{tabular}

Based on the results of the descriptive analysis in table 3 can be concluded that there are differences in speed, and balance of children with special needs children reviewed characteristics of children. This is evidenced from 20 samples obtained differences in average values for speed 6.16 - 7.31 difference 1.15 and balance of 19.75 - 14.66 difference 5.08. Thus, it can be concluded that Karanganyar Special School speed quality and balance are better when compared to Sukoharjo Special School, this is due to one of the characteristics of different regions. Therefore, the role of teachers in reducing the hyperactive behavior of children with special needs varies. Furthermore, after obtaining a descriptive analysis of frequency to 
strengthen the findings in the field can be seen histogram average value speed, and balance of girls in figure 2 .

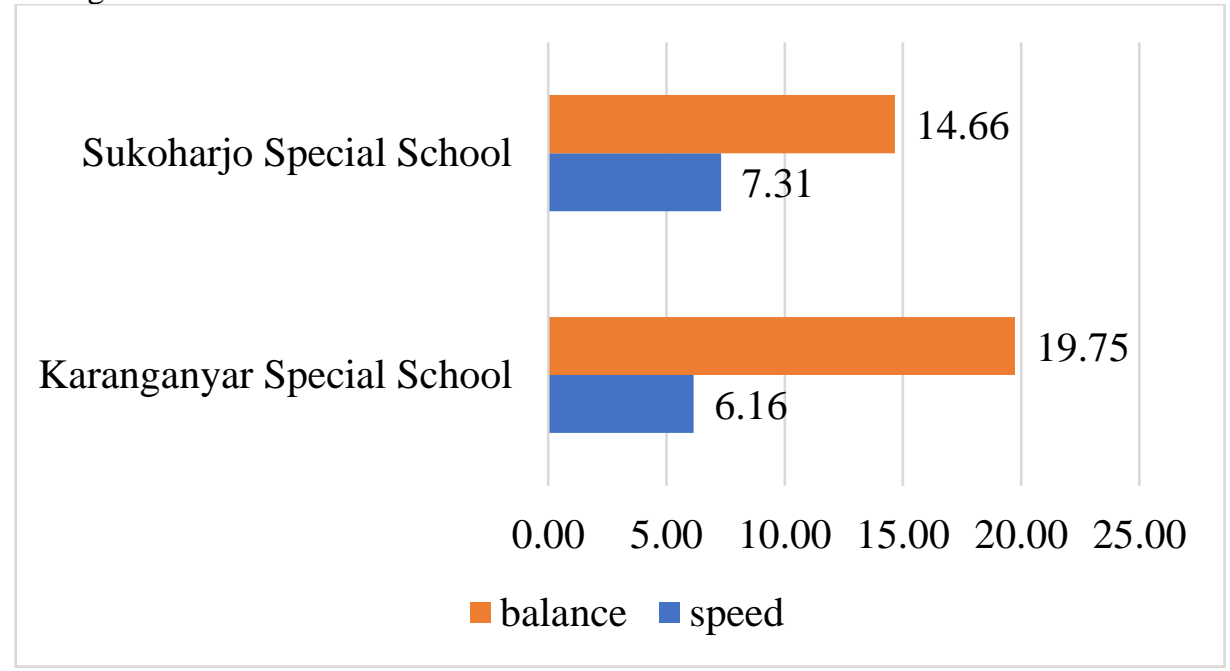

Fig. 1 speed, and balance of female

To prove the significance of differences in the role of teachers in reducing hyperactive behavior of children with special needs reviewed from the characteristics of speed, and balance, it is necessary to conduct statistical testing with "t_test". After the results of the descriptive analysis are described thoroughly then continued with the normality test data using KolmogorovSmirnov Z test (KS-Z) at a significant level $\alpha=0.05$ as a prerequisite for the test of the research hypothesis, while the results of normality of research data can be seen in the normality test table.

\subsection{Data normality test}

Table 4. Data normality test results "speed, and balance" students male

\begin{tabular}{|c|c|c|c|c|}
\hline \multirow{3}{*}{ Statistics } & \multicolumn{4}{|c|}{ Hyperactive behavior of children with special needs } \\
\hline & $\begin{array}{l}\text { Karanganyar } \\
\text { Special School }\end{array}$ & $\begin{array}{c}\text { Sukoharjo } \\
\text { Special School }\end{array}$ & $\begin{array}{c}\text { Karanganyar Special } \\
\text { School }\end{array}$ & $\begin{array}{c}\text { Sukoharjo } \\
\text { Special School }\end{array}$ \\
\hline & \multicolumn{2}{|c|}{ Speed } & \multicolumn{2}{|c|}{ Balance } \\
\hline Number of Samples & 10 & 10 & 10 & 10 \\
\hline $\begin{array}{l}\text { Kolmogorov- } \\
\text { Smirnov Z }\end{array}$ & .951 & .737 & 1.009 & .602 \\
\hline $\begin{array}{l}\text { Asymp. Sig. (2- } \\
\text { tailed) }\end{array}$ & .326 & .648 & .260 & .861 \\
\hline
\end{tabular}


Table 5. Data normality test results "speed, and balance" students female

\begin{tabular}{lcc|cc}
\hline & \multicolumn{3}{c}{ Hyperactive behavior of children with special needs } \\
\cline { 2 - 5 } Statistics & $\begin{array}{c}\text { Karanganyar } \\
\text { Special School }\end{array}$ & $\begin{array}{c}\text { Sukoharjo Special } \\
\text { School }\end{array}$ & $\begin{array}{c}\text { Karanganyar } \\
\text { Special School }\end{array}$ & $\begin{array}{c}\text { Sukoharjo } \\
\text { Special School }\end{array}$ \\
\cline { 2 - 6 } & \multicolumn{2}{c}{ Speed } & 10 & Balance \\
\hline Number of Samples & 10 & 10 & .350 & .724 \\
Kolmogorov-Smirnov & .541 & .918 & 1.000 & .671 \\
Z & .932 & .369 & \\
Asymp. Sig. (2-tailed) & \multicolumn{3}{c}{}
\end{tabular}

Based on the results of the data normality test in tables 4 and 5 Kolmogorov-Smirnov Z (KS-Z) values in all data groups, both sons and daughters turned out to be greater than the value of $\alpha=0.05$. Thus it can be concluded that the sample of this study comes from a normally distributed population. This conclusion provides implications that parametric statistical analysis can be used to test the hypotheses proposed in this study so that the first conditions for hypothesis testing have been met. Furthermore, the homogeneity test is conducted with the Barlett test at $\alpha=0.05$. recapitulation of homogeneity analysis results with Barlett test using Oneway Anova test of homogeneity of variances analysis presented on the homogeneity test table.

\subsection{Homogeneity test}

Table 6. Homogeneity test results

\begin{tabular}{lccc}
\hline Group & $\chi^{2}$ & $\chi^{2}$ a tables $=0.05$ & Sig. $(\mathrm{p})$ \\
\hline $\begin{array}{l}\text { Speed } \\
\text { Balance }\end{array}$ & 1.811 & 18.307 & 0.218 \\
\hline
\end{tabular}

The test results indicate the results of Levene test obtained values of 1,811 and $\mathrm{p}=0.218>$ $\alpha 0.05$ or testing indicates that the value of $\chi^{2}$ counts $=1,811$ smaller than the value of $\chi^{2}$ tables $=18,307$ with a significant degree $(p)=0.218$ so that it is concluded that the eight groups of data tested came from a population with homogeneous variance. Based on both test results the above analysis requirements provide the conclusion that the analysis requirements required for variance analysis are met so that it is feasible to conduct further analysis in looking at the role of teachers in reducing hyperactive behavior of children with special needs reviewed from the characteristics of speed and balance. After the test conditions are met then the hypothesis test is then conducted as for the results of the hypothesis test to know the significance of the role of teachers in reducing hyperactive behavior of children with special needs reviewed from the characteristics of speed, and balance can be seen in table hypothetical test below.

\subsection{Statistical test}

Table 7. T-test data results "speed, and balance" students male and female

\begin{tabular}{lccc}
\hline \multicolumn{1}{c}{ Statistics } & $\mathrm{t}_{\text {-count }}$ & Sig. & $\mathrm{t}_{\text {-tabel }}(0,05)$ \\
\hline The difference in speed male & 2.298 & 0.047 & \\
The difference in balance male & 0.740 & 0.027 & \multirow{2}{*}{1.833} \\
The difference in speed female & 3.614 & 0.006 & \\
The difference in balance female & 1.596 & 0.002 & \\
\hline
\end{tabular}


Based on analysis coefficient of correlation t-test in table 7 above obtained the value of t_count for speed of sons and daughters respectively of 2,298 and 3,614 and greater than t_table $(9 ; 0.05) 1,833$ while for the value of $t$ _count for the balance of sons and daughters respectively of 2,631 and 4,319 and greater than t_table $(9 ; 0.05)$ of 1,833. Based on these results, it can be concluded that the correlation coefficient ( $\mathrm{t}$-test) between speed and balance is significant or $\mathrm{H} 0$ is rejected and received $\mathrm{H} 1$. Thus it can be concluded that there is a significant influence on the role of teachers in reducing hyperactive behavior of children with special needs reviewed from the characteristics of speed, and balance. This means that the coefficient can be generalized or can apply to the overall population of students where a sample of 40 people was taken.

\section{Discussion}

This study was conducted to analyze the role of teachers in reducing hyperactive behavior of children with special needs reviewed from the characteristics of speed and balance. The results of this study were consulted into the literature and the results of previous research, aimed at making reference guides for educators, parents, and stakeholders related to the application of learning for children with special needs in Indonesia through the role of teachers in reducing hyperactive behavior of children with special needs reviewed from the characteristics of speed, and balance. In the context of the literature review, no research has been found related to the role of teachers in reducing hyperactive behavior of children with special needs, judging by the characteristics of speed, and balance. Therefore, the findings of this study are useful as a consideration and reference material to be applied in learning and educating both in the school environment and in the social environment. In the context of research, one of the updates of this study is about the role of teachers in reducing hyperactive behavior of children with special needs is reviewed from the characteristics of speed, and balance, namely how teachers act as educators, mentors, designers/designers of learning, artists/actors, mediators, and motivators to handle hyperactive behavior of children with special needs.

In a study conducted by Volex from the results of the study found that endurance exercises require continuous and structured exercise and accompanied by competent people in their field [12], [13] in the need for self-training exercises that are integrated with the purpose of exercise according to the needs, [14] advance to provide training focus on the transition of quantitative exercises towards quantitative. The point is that quality exercises must be balanced with quantitative exercises to develop individual cognitive. [15] in the process of exercise should learn from sports science so that in the process of exercise obtain useful results, [16] to reduce hyperactive behavior in hyperactive children the need for continuous exercise [17] in his research was put forward to reduce hyperactive behavior of children through learning Sports education, [18] continuous physical exercise to reduce hyperactive behavior of children, and [19] exercises using racquet media to reduce children's hyperactive behavior and improve children's cognitive behavior.

If a review of gender characteristics in children ADHD required mentoring and special strategies in providing learning following the characteristics and needs for hyperactive children [20] suggests fostering a caring attitude in children through social interaction, [21] in reducing hyperactive behavior of children one of which is through the implementation of inclusion schools. Similarly, research conducted by [22] that to meet children with special needs at an early age through inclusion education. [23] in his research stated that inclusive education has 
a positive impact in educating children with special needs both in the school environment and social environment. [24] suggests to reduce hyperactive behavior, especially in children with attention disorders, the need to approach motion training through physical fitness gymnastics exercises, [25] to reduce hyperactive behavior of autistic children the need to pay attention to the school environment and support social family, [26] one solution to reduce the attitude of children is through training skills social, and [27] lifestyle can affect the health of children with special needs.

Looking at the results of the study, the need to study the results of education and teaching research, one of which is through the learning of sports education in reducing hyperactive behavior. As a comparison of the results of research conducted globally. [28] one of the strategies to reduce children's hyperactive behavior is through sports activities, [29] recommendations of the results of this study to reduce the hyperactive behavior of children one of them through athletic exercises accompanied by trainers, similarly, recommended by [30] one of the alternatives to treat children who have hyperactive behavior one of them is through resistance circuit training, and [31] that the results of this study were put forward to increase trust and reduce hyperactive behavior of children one of which is through social interaction through the education of children with special needs.

Thus, it can be concluded that to reduce the hyperactive behavior of children with special needs, one of them is through education and sports learning by involving the role of teachers by considering the characteristics of hyperactive behavior contained in children with special needs following the characteristics of hyperactive behavior of children. One of the updates of this study on the role of teachers in reducing hyperactive behavior of children with special needs is reviewed from the characteristics of speed, and balance indicated by how teachers act as educators, mentors, learning designers/designers, artists/actors, mediators, and motivators to handle hyperactive behavior of children with special needs.

\section{Conclusion}

Based on these findings, the researchers predicted that the role of teachers in reducing hyperactive behavior of children with special needs was reviewed from the characteristics of speed, and balance. The results of this study also contributed to expanding the current knowledge about the hyperactive behavior of children with special needs through the role of teachers in reducing hyperactive behavior through the characteristics of speed, and balance. Since this study only involves a small sample, caution needs to be taken to determine more effective and efficient parenting and learning patterns in children with special needs. However, further research is needed to reduce the hyperactivity behavior of children with special needs taking into account social, psychosocial environmental variables, applying modified motor skills exercises, and those related to problems in reducing hyperactive behavior in children with special needs.

\section{References}

[1] Khairun Nisa, Mambela, S., \& Badiah, L. I. (2018). Karakteristik Dan Kebutuhan Anak Berkebutuhan Khusus. Jurnal Abadimas Adi Buana. https://doi.org/10.36456/abadimas.v2.i1.a1632

[2] Castellanos, F. X., \& Proal, E. (2012). Large-scale brain systems in ADHD: Beyond the prefrontalstriatal model. In Trends in Cognitive Sciences. https://doi.org/10.1016/j.tics.2011.11.007 
[3] Antshel, K. M., \& Barkley, R. (2020). Attention deficit hyperactivity disorder. In Handbook of Clinical Neurology. https://doi.org/10.1016/B978-0-444-64148-9.00003-X

[4] Shaw, P., Stringaris, A., Nigg, J., \& Leibenluft, E. (2014). Emotion dysregulation in attention deficit hyperactivity disorder. In American Journal of Psychiatry. https://doi.org/10.1176/appi.ajp.2013.13070966

[5] Polanczyk, G. V., Willcutt, E. G., Salum, G. A., Kieling, C., \& Rohde, L. A. (2014). ADHD prevalence estimates across three decades: An updated systematic review and meta-regression analysis. International Journal of Epidemiology. https://doi.org/10.1093/ije/dyt261

[6] Faraone, S. V., Asherson, P., Banaschewski, T., Biederman, J., Buitelaar, J. K., Ramos-Quiroga, J. A., Rohde, L. A., Sonuga-Barke, E. J. S., Tannock, R., \& Franke, B. (2015). Attentiondeficit/hyperactivity disorder. Nature Reviews Disease Primers. https://doi.org/10.1038/nrdp.2015.20

[7] Demontis, D., Walters, R. K., Martin, J., Mattheisen, M., Als, T. D., Agerbo, E., Baldursson, G., Belliveau, R., Bybjerg-Grauholm, J., Bækvad-Hansen, M., Cerrato, F., Chambert, K., Churchhouse, C., Dumont, A., Eriksson, N., Gandal, M., Goldstein, J. I., Grasby, K. L., Grove, J., ... Neale, B. M. (2019). Discovery of the first genome-wide significant risk loci for attention-deficit/hyperactivity disorder. Nature Genetics. https://doi.org/10.1038/s41588-018-0269-7

[8] Becker, A., Chaushu, S., \& Shapira, J. (2004). Orthodontic treatment for the special needs child. Seminars in Orthodontics. https://doi.org/10.1053/j.sodo.2004.09.009

[9] Palusci, V. J., Nazer, D., Greydanus, D. E., \& Merrick, J. (2017). Children with disabilities. In Child Abuse: Children with Disabilities. https://doi.org/10.4337/9781786433138.00033

[10] Reindal, S. M. (2008). A social-relational model of disability: A theoretical framework for special needs education? European Journal of Special Needs Education. https://doi.org/10.1080/08856250801947812

[11] Jariono, G., \& Subekti, N. (2020). Sports Motivation Survey And Physical Activity Students Of Sport Education Teacher Training And Education Faculty FKIP Muhammadiyah University Surakarta. Kinestetik : Jurnal Ilmiah Pendidikan Jasmani. https://doi.org/10.33369/jk.v4i2.12449

[12] Volek, J. S., Noakes, T., \& Phinney, S. D. (2015). Rethinking fat as a fuel for endurance exercise. European Journal of Sport Science. https://doi.org/10.1080/17461391.2014.959564

[13] Willcutt, E. G. (2012). The Prevalence of DSM-IV Attention-Deficit/Hyperactivity Disorder: A Meta-Analytic Review. In Neurotherapeutics. https://doi.org/10.1007/s13311-012-0135-8

[14] Williams, D. M. (2008). Exercise, affect, and adherence: An integrated model and a case for selfpaced exercise. In Journal of Sport and Exercise Psychology. https://doi.org/10.1123/jsep.30.5.471

[15] Pesce, C. (2012). Shifting the focus from quantitative to qualitative exercise characteristics in exercise and cognition research. Journal of Sport and Exercise Psychology. https://doi.org/10.1123/jsep.34.6.766

[16] Sharman, J. E., Smart, N. A., Coombes, J. S., \& Stowasser, M. (2019). Exercise and sport science australia position stand update on exercise and hypertension. In Journal of Human Hypertension. https://doi.org/10.1038/s41371-019-0266-Z

[17] Piepmeier, A. T., Shih, C. H., Whedon, M., Williams, L. M., Davis, M. E., Henning, D. A., Park, S. Y., Calkins, S. D., \& Etnier, J. L. (2015). The effect of acute exercise on cognitive performance in children with and without ADHD. Journal of Sport and Health Science. https://doi.org/10.1016/j.jshs.2014.11.004

[18] Ng, Q. X., Ho, C. Y. X., Chan, H. W., Yong, B. Z. J., \& Yeo, W. S. (2017). Managing childhood and adolescent attention-deficit/hyperactivity disorder (ADHD) with exercise: A systematic review. In Complementary Therapies in Medicine. https://doi.org/10.1016/j.ctim.2017.08.018

[19] Gapin, J. I., Labban, J. D., Bohall, S. C., Wooten, J. S., \& Chang, Y. K. (2015). Acute exercise is associated with specific executive functions in college students with ADHD: A preliminary study. Journal of Sport and Health Science. https://doi.org/10.1016/j.jshs.2014.11.003

[20] Pan, C. Y., Chu, C. H., Tsai, C. L., Lo, S. Y., Cheng, Y. W., \& Liu, Y. J. (2016). A racket-sport intervention improves behavioral and cognitive performance in children with attentiondeficit/hyperactivity disorder. Research in Developmental Disabilities. https://doi.org/10.1016/j.ridd.2016.06.009 
[21] Tabi'in, A. (2017). Menumbuhkan Sikap Peduli Pada Anak Melalui Interaksi Kegiatan Social. IJTIMAIYA: Journal of Social Science Teaching. https://doi.org/10.21043/ji.v1i1.3100

[22] Darma, I. P., \& Rusyidi, B. (2015). Pelaksanaan Sekolah Inklusi Di Indonesia. Prosiding Penelitian Dan Pengabdian Kepada Masyarakat. https://doi.org/10.24198/jppm.v2i2.13530

[23] Rahayu, S. M. (2015). Memenuhi Hak Anak Berkebutuhan Khusus Anak Usia Dini Melalui Pendidikan Inklusif. Jurnal Pendidikan Anak. https://doi.org/10.21831/jpa.v2i2.3048

[24] Asiyah, D. (2018). Dampak Pola Pembelajaran Sekolah Inklusi terhadap Anak Berkebutuhan Khusus. Prophetic: Professional, Empathy and Islamic Counseling Journal. https://doi.org/10.24235/prophetic.v1i01.3480

[25] Mirtha, L. T., \& Sekartini, R. (2016). Pengaruh Kepatuhan Latihan Senam Kesegaran Jasmani 1988 Terhadap Perilaku Anak dengan Gangguan Pemusatan Perhatian/Hiperaktivitas. Sari Pediatri. https://doi.org/10.14238/sp18.2.2016.146-56

[26] Saragih, R. S., Zulkarnain, -, \& Sukiandra, R. (2016). Pengaruh Lingkungan Fisik Lingkungan Sekolah Dan Dukungan Social Keluarga Terhadap Perilaku Anak Autis Di Kota Pekanbaru. Photon: Jurnal Sain Dan Kesehatan. https://doi.org/10.37859/jp.v7i01.553

[27] Made Rai, N. G. (2015). Social Skill Training (SST) Sebagai Intervensi Pada Anak Dengan Gangguan Sikap Menentang. Jurnal Social Humaniora. https://doi.org/10.12962/j24433527.v8i1.1242

[28] Sijabat, R. (2018). Gaya Hidup Yang Memengaruhi Kesehatan Anak Berkebutuhan Khusus di SLB Negeri Salatiga. Jurnal Keperawatan Muhammadiyah. https://doi.org/10.30651/jkm.v2i2.1069

[29] Putukian, M., Kreher, J. B., Coppel, D. B., Glazer, J. L., McKeag, D. B., \& White, R. D. (2011). Attention deficit hyperactivity disorder and the athlete: An American Medical Society for Sports Medicine Position Statement. In Clinical Journal of Sport Medicine. https://doi.org/10.1097/JSM.0b013e3182262eb1

[30] Wolfe, E. S., \& Madden, K. J. (2016). Evidence-based considerations and recommendations for athletic trainers caring for patients with attention-deficit/hyperactivity disorder. Journal of Athletic Training. https://doi.org/10.4085/1062-6050-51.12.11

[31] McKean, C. C., Baiamonte, B. A., Kraemer, R. R., \& Hollander, D. B. (2018). Attentiondeficit/hyperactivity disorder medication does not alter exercise-induced hypoalgesia following an acute bout of dynamic circuit resistance exercise. Biology of Sport. https://doi.org/10.5114/biolsport.2018.77837

[32] Rezaei, M., Kamarzard, T. S., \& Razavi, M. N. (2018). The effects of neurofeedback, Yoga interventions on memory and cognitive activity in children with attention deficit/hyperactivity disorder: A randomized controlled trial. Annals of Applied Sport Science. https://doi.org/10.29252/aassjournal.6.4.17 